Arabindoo, P. (2011). Mobilising for water: hydro-politics of rainwater harvesting in Chennai, International Journal of Urban Sustainable Development, 3:1, 106-126 


\title{
Mobilising for water: Hydro-politics of rainwater harvesting in Chennai
}

\begin{abstract}
In 2003-04, as the Indian city of Chennai faced an unprecedented water crisis, a debate ensued about finding longer-term sustainable solutions, ranging from expensive desalination plants to modest rainwater harvesting schemes. The latter was enforced by an authoritative state and promoted enthusiastically by environmentalists to raise awareness about the city's much destroyed hydrological ecosystem. In contrast to the state's interpretation reducing it to a compulsory hydraulic installation in individual buildings, environmental NGOs made a concerted effort to develop a more comprehensive intervention in the wider public domain. However, as a dizzying array of socio-political actors came together, concerns emerged about the ability of such a mobilisation to generate a uniform material understanding of rainwater harvesting as a common moral goal. Examining in detail one specific case study of a communityled effort-Puduvellam, this paper looks at how, as a grassroots organisation involved in the restoration of a prominent temple tank in southern Chennai, it rallied support amongst the local (mainly middle class) residents to create a new topology of ecological consciousness. Its success however was only partial and highlights the futility of romanticising rainwater harvesting as an indigenous alternative. More importantly and ironically, its ineffectiveness was enhanced by the crisis itself as it triggered a process of privatisation and commodification of water, with rainwater harvesting eventually being absorbed by the agenda of 'bourgeois environmentalism'.
\end{abstract}

Keywords: Chennai, water crisis, rainwater harvesting, middle class, residents' associations, grassroots, 'bourgeois environmentalism' 
Residents of Chennai City are aware of the unprecedented failure of the North East Monsoon in 2003 leading to the City's worst ever water crisis. In the recorded history of 54 years for which data is available, never has Chennai experienced such an acute drought. This led to the lowest storage levels as at the end of December, 2003...... [and] represented only 35 days of supply at 250 MLD. Chennai was thus facing the grim prospect of water famine and even evacuation.

- J Jayalalithaa, Chief Minister of Tamil Nadu (05 August 2004) ${ }^{1}$

The year 2004 will be long remembered by the residents of city as the worst ever in scarcity of water.

- M Rangaswamy, Korattur. (Readers's Mail, The Hindu, 15 November 2004)

In 2003-04, Chennai, the capital city of Tamil Nadu in southern India, faced an unprecedented water crisis following the recurrent failure of monsoon rains for a few consecutive years. ${ }^{2}$ Even though water scarcity has been a consistent feature in the city's everyday problems, during this particular period, the city's reservoirs dried up completely and piped water supply system was virtually shut down, prompting speculation that the city might have to be evacuated if the situation did not improve. ${ }^{3}$ As officials struggled to resolve the city's immediate needs, this epic shortage sparked a debate about devising a longer-term, more reliable and sustainable water management strategy. While politicians favoured the flashy and expensive solution of desalination plants and economists at the development banks concentrated on improving the efficiency of the water supply and distribution system, the environmental lobby in the city launched a vigorous campaign of rainwater harvesting to recharge the city's depleted aquifers (Srinivasan 2008; Srinivasan et al. 2010).

\footnotetext{
${ }^{1}$ Press note no. 146 released by the Government of Tamil Nadu. http://www.tn.gov.in/pressrelease/archives/pr2004/pr050804/pr050804.htm [retrieved on 12 October 2010].

${ }^{2}$ Madras was renamed as Chennai in 1996. In the postcolonial years, the city has experienced water supply crisis at least once every decade, most notably in 1968, 1973, 1986, and 1993-94. The failure of the Northeast monsoon in 2001, 2002 and 2003 aggravated the situation to an extent not experienced before, resulting in the mega-crisis of 2003-04.

3 In this period, the Chennai Metropolitan Water Supply and Sewerage Board (CMWSSB) or Metro Water as it is popularly known, supplied the city with 200 MLD instead of the normal 600 MLD. Most residents found themselves coping with only 20-30lpcd rather than their regular supply of 901pcd. Chennai is one of the worst served cities amongst the Indian metros in terms of everyday water provision. Piped supply is only for a few hours and not guaranteed on a daily basis. In 2007, the second master plan by the Chennai Metropolitan Development Authority (CMDA) estimated a daily supply of $1051 \mathrm{lpcd}$, which is still far less in comparison to other cities such as Delhi (270lpcd), Mumbai (260lpcd)
} 
Amidst the state's capital-intensive, mega- engineering efforts to bring water from far-off sources and exploring the potential of desalination plants, it was the modest rain water harvesting initiative that became a mantra of sorts during the crisis. The latter was already a buzzword in circulation when, following erratic water supply in the earlier years, the state passed a Municipal Laws ordinance in July 2003 making rainwater harvesting mandatory for all buildings. ${ }^{4}$ The 2003-04 crisis highlighted the critical role it could play in restoring the city's fragile and much destroyed hydrological ecosystem. But this discourse of rainwater harvesting emerged at a worryingly paradoxical moment when, with rain-fed surface water reservoirs drying up, city officials and residents/businesses resorted to indiscriminate ground water extraction through a range of formal and informal arrangements with private water tanker companies. ${ }^{5}$ Also, in most instances, rainwater harvesting came to be interpreted as simply collecting rainwater with state regulations merely stipulating that individual buildings have some semblance of rainwater harvesting feature in place. This is of course insufficient to repair the city's eco-terrain, and while the state did endeavour at places to demonstrate a more comprehensive intervention in the wider public domain, such efforts mostly relied on the active leadership of environmental NGOs in the city.

Promoting it as a small-scale, low-technology, low-cost indigenous practice with established historical precedents and appealing to all classes, environmental groups took up the cudgels of repairing and restoring several dried up tanks in the city that had almost disappeared due to encroachments. Entailing a dizzying array of socio-political actors, this initiative seemed to be suggestive of Appadurai's (2002)

and Kolkata (225lpcd). According to Janakarajan et al. (2007), in reality, the supply is even less at 761 lpcd.

${ }^{4}$ Rainwater harvesting as mooted by the state dates back to the 1980 s when it was identified as an alternative to groundwater extraction in the 1987 Chennai Metropolitan Area Groundwater (Regulation) Act. In 1994, the Chennai Metropolitan Development Authority (CMDA) and the Corporation of Chennai adopted a statutory approach where specific buildings were given planning permission only if they incorporated a rainwater harvesting system in their proposal. In 2002, the 1987 Act was amended to make rainwater harvesting compulsory in all buildings in the state. Due to its poor implementation the ordinance was reworded as the 2003 Act which was more authoritative and threatened disconnection of water supply if residents and businesses failed to comply.

${ }^{5}$ Nearly 1000 tankers operated during the crisis period making 13,000 daily trips of which at least 10,000 was commissioned directly by Metro Water. This considerable amount of groundwater 
new model of local democracy or what he calls as "deep democracy", where the local activism of grassroots movements is enacted through a 'politics of partnership' between traditionally opposed groups, such as the state, civil society groups and local communities, nurturing unexpected forms of alliances towards longer term capacity building. Even though partners may not hold common moral goals, the emerging 'new geographies of governmentality' ensures that differences are negotiated through a politics of accommodation, i.e. inclusion, participation, transparency and accountability (ibid.).

While Appadurai (2002) concludes by placing faith in the capability of communities and their grassroots activism to perform as powerful local instruments of deep democracy, the question of whether such a mobilisation has an enduring sociopolitical capital remains. Also of issue is the valorisation of civil society by deep democracy even though the former can be undemocratic and hierarchical. In fact, arguing against a simplistic understanding of deep democracy, Roy (2010) views grassroots organisations not as a mediating bridge between the "state up there" and the "community down here" but as one that both resists and complies with top-down forms of rule. In the case of grassroots environmentalism that is celebrated for conceptualising protest and struggle by respecting difference, concerns have emerged over their ability to remain close to 'where people are', as they not only risk either cooption or isolation by the state and other powerful institutional actors, but also have to cope with the challenge of dealing with highly differentiated groups with unequal access to power, prestige, income and capital. In such a condition, grassroots activism is not necessarily empowering but instead can produce its own elite vehicle of knowledge circulation.

Such concerns are particularly relevant in the case of rainwater harvesting which, since Agarwal and Narain's (1997) description of the technique as a Dying Wisdom and their passionate call for its revival, has emerged in several cities and regions as an alternative to water resources management currently dominated by public/private utility companies. Often developed as a community-level grassroots 
initiative, rainwater harvesting promises a new countertopography where the ecological realities of unsustainable development can be redressed. However, in recent years, despite an overwhelming sense of support for this practice, scholars are adopting a critical position suggesting that its potential may be overstated. Kumar et al. (2006), for example, argue that there is little scientific evidence regarding the impact of localised water harvesting activities on the recharge of water basins. Marked by the absence of hydrological planning and sound economic analysis, they argue that its ability to rectify the demand-supply imbalance is limited. Case studies of specific schemes highlight its failure to strengthen community institutions despite being developed as a community-led strategy (Kashwan 2006). Driven by the efforts of NGOs and community-based organisations, rainwater harvesting schemes are challenged by the different environmental imaginaries that result from internal heterogeneities and power asymmetries within the communities. In the urban context, attention is also being drawn to the fact that the state-led model of roofwater harvesting cannot be the basis of a new paradigm in terms of urban water management (Maria 2008), particularly when as a system it is more suited to the permanent structure of the cities' elite and middle class residences rather than the temporary shelter of the poor (Kumar 2004). This is endorsed by Veron (2006) who views rainwater harvesting as a middle class campaign to ensure increased direct water availability for the better-off mainly. The paradox here is that in spite of its seemingly middle class agenda, rainwater harvesting overlaps with the spread of more profligate uses of water by the city's middle classes, whose changing patterns of consumption not only undermines efforts at water conservation (Gandy 2008), but also underlines the contradictory and insincere nature of 'bourgeois environmentalism' (Baviskar 2003).

This was clearly seen in the case of rainwater harvesting in Chennai against the backdrop of the 2003-04 water crisis. For, unlike Appadurai's (2002: 29) optimism about a 'politics of patience' accompanying such efforts, the urgency of the problems assailing local residents tends to take over with their attention distracted by the pressing concern of finding imminent quick-fix solutions to the water crisis. Also, as rainwater harvesting is adopted by different actors, it is subject to active reinterpretation and reappropriation according to their own socio-political agendas and context-specific realities. Their epistemologies and ontologies are informed by 
concepts set within their own class and identity-based arguments, and there is a good chance that they will not resonate together towards a greater common good but might instead deploy tactics to achieve a narrower set of vested interests. This potentially limits the transformative politics of rainwater harvesting and its ability to act as a paradigm of sustainable urban water management.

In many ways, the crisis offered a perfect setting to explore rainwater harvesting as something more than a hydrological ideal. As McFarlane and Rutherford (2008) have argued, the politics underpinning urban infrastructural transformation are rarely more evident or visible than in times of crisis with the underlying power geometries becoming more perceptible. It is in this context that this paper investigates the local community-based rainwater harvesting effort in the city called Puduvellam. Set in the southern neighbourhood of Thiruvanmiyur, this grassroots initiative involved the restoration of a culturally important temple tank as a prominent source of groundwater recharge, with its activities peaking during the 2003-04 water crisis. Activists leading the project hoped that it would serve as an exemplar for a micro-level, community-led effort in creating a new topology of ecological consciousness. The complex terrain of socio-political debates embedded within the project however reveals the challenge of reconciling the perspectives of different actors involved to generate a uniform material understanding of rainwater harvesting. Some of the issues are rooted more in the historical nature of Chennai's persistent water crisis, and hence, before unpacking the details of Puduvellam per se, it is important to understand the evolution of Chennai's hydro-geography. This background is provided in the next section which summarises the historical circumstances under which the city's water infrastructure (mal)developed. This is followed by a discussion of how its residents mobilised for water, collectively bargaining with a resource-starved state, affecting their perception of water as a public good, particularly during the crisis periods. The record scarcity in 2003-04 generated specific responses amongst its residents to procure water, with the buzz of rainwater harvesting appealing to several who incorporated it within their coping strategies. Intersecting at a particular moment where changing lifestyles of an increasingly consumer-oriented middle class coincided with the water crisis, rainwater harvesting efforts revealed contradictions in the way the state and the environmental lobby were redefining the city's socio-ecological discourse. This is revealed through an analysis 
of Puduvellam with the penultimate section discussing the endurance and effectiveness of Puduvellam as a grassroots initiative and rainwater harvesting in general. Participant observation and interviews were conducted in 2003-04, allowing a live examination of its progress. This provided an in-depth understanding of how the priorities of those involved influenced not just the level of their participation but also how their prejudices redefined its outcome.

\section{Rhetoric and reality of Chennai's hydro-geography}

Despite $88 \mathrm{~km}$ of waterways within the city limits including two rivers and four canals, Chennai has traditionally been known to be a water-starved city. ${ }^{6}$ It is also surprising that with $1200 \mathrm{~mm}$ of average annual rainfall, Chennai fares much better than the national average of $800 \mathrm{~mm}$ that most Indian cities including Delhi, Bangalore and Hyderabad receive. But since most of its rainfall is concentrated during the limited monsoon months, excessive precipitation is lost in untapped run-offs and floods. This, combined with other ecological realities resulted, in the pre-colonial times, in the development of a man-made, rain-fed water system involving an elaborate network of inter-connected reservoirs (eris), tanks, lakes and ponds. Managed as common property resources at an autonomous village level, this tank-based indigenous ecosystem represented an extended habitat in the region, and served as a repository of economic, political and cultural capital (Mosse 1997a, 1999; Vaidyanathan 2001, 2006; Palaniswami and Meinzen-Dick 2001; Sakurai and Palaniswami 2001; Janakarajan 1993; Ludden 1979).

A cursory look around the landscape today reveals that most of these tanks and reservoirs are either in disrepair or have disappeared, indicating a break in the pre-colonial resource flows and its circuit of investment. While an ideological argument is generally built against the colonial state whose centralised revenue and administration system activated a collapse of the traditional system of segmentary resource management (Sengupta 1985; Reddy 1990; Agarwal and Narain 1997; Mukundan 1988), Mosse (1999, 2001, 2003) clarifies that even though colonialism did catalyse its deterioration, this is not entirely correct as a decisive moment of loss 
can be located in different histories as one chooses to. However, in Chennai, it was quite clear that the pre-colonial tank-based water resource system had became redundant by the mid-nineteenth century as a new political economy of water emerged under the colonial administration, shaped by the western Enlightenment era's science, engineering and capitalist production processes. At the time of its colonial foundation in 1639, Chennai was basically a gathering of highly organised agrarian villages centred around temples and with strong associations to rural south India. Even though the original English settlement hardly impinged on the agrarian society, its eventual expansion in the 1700s and 1800s absorbed the villages and disrupted their agrarian order (Lewandowski 1975, 1977, 1979; Kosambi and Brush 1988; Neild 1979). As the Europeans moved into large residential suburban tracts, it interfered with existing irrigation systems as a result of which, between 1798 and 1830, the amount of cultivable land decreased from 3600 acres to 565 acres (Neild 1979; Figure $1)$.

Insert Figure 1 here

In 1872 a new water supply system was introduced when water from the Kortalaiyar River to the north of the city was diverted to two reservoirs - Cholavaram and Red Hills - from where it was delivered to a central pumping station and distributed through the city via an underground piped system literally burying the visible relationship between nature and the city (cf. Kaika and Swyngedouw 2000). The peculiarity of the colonial condition including the "fiscal conservatism" of the colonial administration and the social indifference of the city's European and indigenous elites, exposed a fundamental inability of the municipal administrators to coordinate development projects for the city as a whole resulting in a process of "incomplete modernity" (Gandy 2006). Infrastructure improvements dotted the cityscape in a disjointed manner, marked by an inequality of access amongst the different population groups. ${ }^{7}$ This distortion manifested itself in frequent spurts of

\footnotetext{
${ }^{6}$ Chennai city covers a total area of $174 \mathrm{~km} 2$. At the metropolitan level however, the length of waterways crisscrossing its $1189 \mathrm{~km} 2$ is only double at $158 \mathrm{~km}$.

${ }^{7}$ McFarlane (2008a: 354; 2008b) emphasises this as a key difference between infrastructure-led modernisation in the Euro-American context and the global South. While in the former, "infrastructures, as a historically important part of the "modernist ideal" of the uniform, integrated
} 
water shortages paralleled by public health crises, exposing as a result an inefficient supply system (Krishnaswami (1994 [1939]).

This dynamic continued into the post-independent period as the city inherited the colonial infrastructure of centralised urban planning, resulting in a postcolonial predicament of sorts when the social transformation of nature was severed even more from urbanisation and adversely affected by the phenomenon of hyper-urbanisation that plagued postcolonial Indian cities. In Chennai, a unique kind of postcolonial regime developed where, with the rise of the Dravidian movement, a sub-regional and ideologically constructed Tamil cultural nationalism resulted in the pursuit of populist policies broadly based on clientalist-machine politics with a paternalistic focus on the personality-cult status of its leaders. ${ }^{8}$ Obsessed with infusing the city's spaces with a Tamil identity, its civic projects were limited to the raising of statues and building monuments (Srivatsan 2000, 2006). There was no room for developing the city's infrastructure and its physical well-being, and the city began to show strains, as seen in its water supply statistics where between 1950-51 and 1968-69, even though the supply doubled from $75 \mathrm{mld}$ to $140 \mathrm{mld}$, its per capita daily supply only slightly increased from 531pcd to 64lpcd, much less than the 1931-32 average of 1101pcd (MMDA 1971).

The regional parochialism and economic radicalism of Dravidian politics resulted in development schemes that came across as '[e]mbodied metaphors of kingship to produce affective attachment among the governed' (Hancock 2008), and were based on unsound fiscal policies (Washbrook 1989; Rudolph 1961). Thus, when Chennai encountered its first major water crisis in the late-1960s, the state announced the mega-scale Veeranam Project in 1968 to convey 40mld of water in pipes from the Veeranam tank, $225 \mathrm{~km}$ south of Chennai. Although at one level such a proposal echoes a national confidence in large-scale development projects from the Nehruvian

equally serviced city, have become increasingly fragmented through processes of deindustrialisation, privatisation and reduced state spending', the urban fabric has always been fragmented in the latter.

${ }^{8}$ There have been several academic publications on the history and character of Dravidian politics. While Barnett's (1976) The Politics of Cultural Nationalism in South India is a classic, more recently, Widland's (2000) Paths to power and patterns of influence: the Dravidian parties in South Indian politics and Subramanian's (1999) Ethnicity and populist mobilization : political parties, citizens, and democracy in South India have provided an updated analysis of Dravidian politics. 
era of high modernity, this solution emerged from the specific agenda of Dravidian politics, seen less as an engineering marvel and more as one powered by the regal largess of a benevolent leader - the then Chief Minister CN Annathurai. ${ }^{9}$ But the lack of proper planning and the irrationality of the Dravidian state policies resulted in the project's failure. After several corruption scandals including poor construction and financial mismanagement, the project was scrapped in the mid-1970s.

This was replaced in 1976 by yet another hydraulic engineering scheme, the Krishna Water project. Popularly known as the Telugu Ganga Project, it proposed to bring water annually to Chennai from Krishna River in the neighbouring state of Andhra Pradesh. ${ }^{10}$ The project was however considerably delayed, starting in 1983 and finally completed in 1997. But, instead of the promised 12TMC of water, only $0.5 \mathrm{TMC}$ was released in the beginning, improving in recent years to a modest yet insufficient 5TMC. Nevertheless large-scale water engineering strategies remain a distinct element of authoritarian governmentality. Schemes such as the Veeranam project despite their history of failure persisted in the state agenda, with the Anna Dravida Munnetra Kazhagam (ADMK, a rival Dravidian party to the DMK) government making it central to the tackling of the 2003-04 crisis. When the Veeranam Tank dried up the state was forced to extract water from the nearby Neyveli aquifer and the Coleroon riverbed. This provoked protest from the surrounding farmers and the proposed extension to the New Veeranam Project had to be dropped. A postcolonial historiography of science and technology in India reveals how the state's agenda shifted from techno-nationalism to techno-populism with the compulsions of electoral politics forcing a supply-oriented engineering ethos. Water engineering in this context became a poorly realised ideology underwritten by a means-ends-necessity approach. In this context, even environmentally conscious

\footnotetext{
${ }^{9}$ Ironically, Veeranam tank is an eleventh-century reservoir built by the Cholas (a famed Tamil dynasty) to harvest water from the Cauvery river basin, an epitome of pre-colonial water resource management.

${ }^{10}$ Both the Veernanam and Krishna water projects evolved from an understanding that Chennai's water scarcity problem is mainly due to its non-riparian geography, one that could be rectified by linking it to the nearest riparian system, namely the Cauvery River basin to the south or the Krishna River to the north. This argument resonates to a certain extent with the national discourse on inter-linking of rivers in India, which has been dodged by ideology and dogmatism, rather than a clear, techno-scientifically informed thinking. While the debate makes a case that the perennial rivers of the north can be linked with the rain-fed rivers of the south in a complex network of canals to reinforce an ecologically homogenous terrain, there continues to be much scepticism over its economic and environmental feasibility (Bandyopadhyay and Perveen 2004; Vaidyanathan 2003).
} 
initiatives such as rainwater harvesting are forcibly cut to fit this mould compromising its ecological sensibilities to a great extent. More importantly, this small-scale technological response is reduced to the same objective of simply augmenting raw water availability as the gigantic, techno-managerial ones without really addressing the problem of an uneven water supply distribution system. As a result, both solutions contribute to a fragmented infrastructure and enhance socio-ecological inequities in their own ways.

\section{Mobilising for water}

As the postcolonial years came to be marked by irrational planning of Dravidian populist politics, it didn't take the city's residents long to realise that if they were not to choke in a system that was hardly reminiscent of a modern development feature, then, they (whether the rich, the middle class or the poor) would have to organise themselves collectively to obtain the basic facilities. Thus, residents found themselves playing a significant role in the shaping of local landscapes, through varying degrees of self-management. Each class used their own means and methods of procuring what the municipality had failed to provide, and in many cases, different social groups found themselves competing with each other for the limited services offered by an under-resourced state. ${ }^{11}$ In middle class neighbourhoods, faced with unreliable public water supply, the collective action of their residents' associations became critical to the pursuit of their welfare needs as they resorted to self-service mechanisms for water supply (relying on wells/bore wells). During crisis periods, these associations bargained(formally and informally) with Metro Water for piped as well as tanker water supply in addition to private water suppliers. In 2003-04, amidst a flurry of different coping strategies, while residents' associations were hurriedly installing rainwater harvesting features to appease the state, they found themselves being solicited by environmental NGOs for their support in taking rainwater harvesting to a wider, more meaningful scale beyond just a 'ticking the box' exercise. This is not surprising given the "middle-class culture of public life" (Mawdsley 2004: 81) where

\footnotetext{
${ }^{11}$ Upper classes employed elitist manipulation of both the political and bureaucratic state to ensure that resources were diverted to serve their private ends (reproducing the behaviour of the Europeans and native elites during the colonial era). The middle class mainly petitioned the bureaucratic state for necessary infrastructure, while the poor resorted to agitated forms of protests in the political terrain through a clientalist bargaining with their political leaders.
} 
'the middle classes exert a disproportionate influence in shaping the terms of public debate on environmental issues through their strong representation in the media, politics, scientific establishment, NGOs, bureaucracy, environmental institutions and the legal system' (ibid.; $c f$. Harriss 2005, 2006, 2007).

This is however a daunting task for residents' associations which are mostly small associations based on interpersonal relations sans the notion of "public" or social trust. Unwilling to assume public responsibilities, they are little more than cliques and cabals (Gupta 2001). In addition, as a 'paradigm of propertied citizenship' (Roy 2003) they are generally bound by the sensitivities of their private property and often impose a negative externality on what is outside their residential complex. Given their narrow sense of voluntary action, it is hard to describe their function as "deep democracy". Formed mostly in response to the infrastructure crisis of a modernising Third World city, their survival-based approach indicates their reluctance to initiate policy changes. On the other hand, following the recent focus on the new middle class in India (Fernandes 2006), studies on middle class residents' associations have portrayed them as a countervailing power to a bureaucratic state, providing the middle class with a basis for claiming their right to the city (Zerah 2007; Baud and Nainan 2008; Lama-Rewal 2007; Anjaria 2009). But Kamath and Vijayabaskar (2009) caution that there are limits to their collective action as the influence of their associational life on their extended public domain is misplaced and exaggerated. ${ }^{12}$

Perhaps a better way for these associations to expand their activities into the public sphere without being limited by self-concern would be to align with formal civil society institutions which are believed to have a greater level of socio-political consciousness and a better capacity to create spaces of democracy. This dynamic is explored in the following section by examining the efforts of Puduvellam, a local community-based organisation which joined the city chapter of a national NGO, Indian National Trust for Art and Cultural Heritage (INTACH), to renovate the

\footnotetext{
${ }^{12}$ This is not unlike the western literature on residents' associations, where some consider them as producers of a well-deployed stock of social capital (Butler and Robson 2001) while others view them suspiciously, aligning them with the privatopia discourse (Davis 1992).
} 
prominent Marundeeswarar Temple in Thiruvanmiyur and emphasise the benefits of rainwater harvesting. ${ }^{13}$

\section{Puduvellam and the sacred science of rainwater harvesting ${ }^{14}$}

Although a southern neighbourhood in Chennai today, the origins of Thiruvanmiyur traces back to an ancient village steeped in legendary narratives. The Marundeeswarar temple and its five main water bodies, two wells inside the temple complex, two tanks, and a large lake nearby were celebrated by the sacred texts for its holy redeeming qualities. Adjoining the village is Thiruvanmiyur kuppam, the fishermen hamlet with a historic relationship with the temple and the village. In recognition of this geneology, the upper middle class neighbourhood that developed south of the village in the 1950s comprising of exclusive residences for elite bureaucrats was called Valmiki Nagar. ${ }^{15}$ Thiruvanmiyur was a distant suburb to the city till the extension of the Corporation boundary in 1978 brought in a bevy of infrastructural improvements creating a demand for housing amongst the growing middle class. In the 1980s and 1990s, the state-run Tamil Nadu Housing Board (TNHB) completed rather contentiously a middle-class housing scheme in Valmiki Nagar and developed the adjoining Thiruvalluvar Nagar for the lower-middle class (Arabindoo 2009; Figure 2). Despite this socio-spatial fragmentation and the accompanying pressure of development/encroachment, the temple remains an important site of socio-cultural activities.

As the restoration of neighbourhood temple tanks became an important step in the agenda of rainwater harvesting in a wider public domain, the centrality of the temple with its vast tank complex to the surrounding settlement became even more significant. ${ }^{16}$ Their rehabilitation however cannot be romanticised as a revival of an

\footnotetext{
${ }^{13}$ Formed in 1984, INTACH is an elite NGO whose membership base draws from the Englishspeaking middle class and is funded mostly through donations and occasional grants. More details about their activities is available on their website http://www.intach.org.

${ }^{14}$ Puduvellam means new water in Tamil

${ }^{15}$ One of the ancient manuscripts mentions that the great sage Valmiki- the author of the famed Indian epic, the Ramayan-worshipped Lord Shiva here as Vanmikanathar and therefore the village was named Thiruvanmiyur.

${ }^{16}$ A 2002 report by the CPR Environmental Education Centre mentions that there were a total of 124 eris and 50 temple tanks within the Chennai metropolitan area at the time of colonisation. Chennai city today has 39 temple tanks in addition to the several eris or artificial tanks to harvest the rain water. The
} 
ideal, ecologically embedded pre-modern water irrigation technology as many tend to do. Temple tanks as a techno-sociological artifact signified a pre-colonial regional economy that sustained an unequal social hierarchy (Shah 2008; Mosse 1997a, 1999). In the postcolonial period, despite their reduced relevance to the typology of the modern built environment, they continue to reinforce power relations which have a heightened chance of being reproduced through their revitalisation. The promotion of temple tank based rainwater harvesting is a complex task involving an intricate negotiation of social tensions, relations, power, and ideology as well as the baggage of historical processes.

Insert Figure 2 here

In 1998 INTACH launched its 'Places for People' programme which was meant to preserve indigenous lifeways and its socio-spatial fabric. As an exemplar it undertook the restoration of the Marundeeswarar Temple tank and the redesigning of its landscape. For INTACH this was not only about improving the temple's appearance but also demonstrating the effectiveness of preindustrial methods of water harvesting where cultural and environmental conservation was pursued collectively. Time and again, employing the normative language of civil society, NGOs or community-based organisations have tried to work in a 'public-private partnership' to rehabilitate the tank which has been dry for several decades. But in most cases this has been unsuccessful including the 1993 attempt by the Rotary Club of Madras along with Valmiki Nagar Residents' Association to desilt the tank and harvest rainwater.

INTACH nevertheless presented a draft conservation plan for the temple and its tank complex in 2000 (Figure 3). It recognised the need to involve different state actors, including the Corporation of Chennai, Public Works Department/PWD, the Hindu Religious and Charitable Endowments/HRCE, Metro Water, the Highways Department and the Archaeological Survey of India, and also elicited the opinion, if

second Master Plan prepared by CMDA mentions that there are about 320 tanks/lakes that were earlier used as water source for irrigation within the metropolitan area and which now function mostly as flood accommodators. This does not include the large number of ponds and the network of lakes, canals and channels within its boundary. In 2003, the state department of Hindu Religious and Charitable Endowments (HRCE) along with the Corporation of Chennai announced the restoration of the 
not outright participation, of local residents, businesses and community organisations. It was in the shadows of this proposal that Puduvellam was established as a grassroots response to bring together community support for the tank restoration. While on paper the task of overlapping the socio-ecological politics of rainwater harvesting with the larger debate of the temple as a public space seemed easy, in reality it proved to be quite difficult testing the ability of a small-scale initiative such as Puduvellam to negotiate and manoeuvre through this complex landscape.

Insert Figure 3 here

In 2003, a well-hearted environmental activist from the middle-class neighbourhood of Valmiki Nagar formed the community-based organisation, Puduvellam, to join causes with INTACH's project. Given the topical concern of water crisis and the fact that Thiruvanmiyur was one of the neighbourhoods affected by Metro Water's indiscriminate extraction of the southern coastal aquifer, the founder of Puduvellam was convinced that this grassroots level activism was an ideal platform for demonstrating the effectiveness of harvesting rainwater in the wider public domain. He made a commitment to partially fund the renovation (offering to contribute 25 percent of the estimated cost of the project, with the remaining 75 percent coming from the Corporation). ${ }^{17}$ To this end, Puduvellam organised a Children's Art Festival on the theme of conservation and water, held within the large tank in March 2003, and raised money from the sale of greeting cards. Later in August, Adi Perukku, a Hindu ritual was held in the smaller tank. Finally on 10 and 11 January 2004, a neighbourhood festival, Thiruvanmiyur Thiruvizha, was held around the temple tank area with music, dance and competitions for women, youth and children. ${ }^{18}$ Unfortunately for Puduvellam, these events failed to highlight the woods

documented 39 temple tanks in the city as part of its commitment to rainwater harvesting. But, little headway has been made in most cases.

${ }^{17}$ INTACH on the other hand sought to control the project with its recommendations but made no commitment to funding.

${ }^{18}$ In another neighbourhood in the city, centred as well around a historic temple and its tanksMylapore - the residents launched an environment-based development initiative called 'Namma Mylapore' in collaboration with INTACH to revitalise this historic district. A Mylapore Festival is held annually, organised by the local neighbourhood newspaper, Mylapore Times, with much publicity and some generous support of corporate sponsorship. But, the primary objective of restoring the tank for rainwater harvesting remains only partially realised given the real estate pressures of its surrounding landscape and the dilution of its rehabilitation agenda to a visual concern. Thiruvanmiyur Thiruvizha on the other hand has not taken place since 2005 due to lack of funds. 
for the trees with its core objective being lost on the middle class residents. Residents attended the festivities enthusiastically, but not many committed as volunteers to Puduvellam's agenda which sought a more rigorous participation in cleaning the tank.

While many residents described Puduvellam as a good effort, they seemed removed from and indifferent to its objectives. A long-time resident of Valmiki Nagar, an ex-government official, when asked about Puduvellam said that 'they are doing good work I am sure they are but....they have not exerted themselves to reach out to the people here' (emphasis added). He described Puduvellam as well-meaning people, but insisted that people in Valmiki Nagar are not all that interested. Many residents when interviewed claimed that they did not have first-hand information about Puduvellam as their participation was not solicited directly by personal door-to-door requests, and that they got to know about it only through reports in the local newspaper. Puduvellam advertised regularly in the neighbourhood weekly Adayar Times, with details about the organisation as well as special events including festivals and cleaning-up days. Much of the information was lost on an average reader, whose eyes train on items with entertainment value such as festivals, ignoring the volunteering request. Puduvellam officials clarified that personal door-to-door campaigning did take place with pamphlets distributed to every household, but few responded. For most Valmiki Nagar residents, Puduvellam was something that is outside of the Valmiki Nagar community, and hence they associated it more with Thiruvanmiyur village. Even though Puduvellam was started by a resident of Valmiki Nagar, others in the neighbourhood struggled to find common cause as a community.

Quite a few members did take up the brooms and spade on weekends to clean the tank but such gestures remain nominal given the arduous physical labour required on a more consistent basis. A middle-class supporter who participated in this exercise saw it as a fantastic objective but one that has to struggle against the wave of rigid Hindu traditions that prohibit such community-based actions. If the residents of Valmiki Nagar do not want to get their hands dirty, it is because there are fundamental socio-religious strictures attached to this reluctance, where the prevalent caste hierarchy creates a distinction between a clean inside and a dirty outside, and attaches social stigma to garbage and its collection (Kaviraj 1997; Chakrabarty 1992). Bound by their upper class/caste prejudices and privileges, middle class residents tried to 
resolve the water crisis differently from Puduvellam's long-term, grass-roots strategy. They acknowledged the need for a comprehensive environmental strategy to manage the water crisis, but only at an abstract level. Their preference is to purchase water from private suppliers or installing treatment plants for gray water recycling which, according to one resident, addresses better the 'problem at hand'. The paradox here is that while Puduvellam was trying to recharge groundwater within its immediate vicinity, residents continued to rely on groundwater from other sources (supplied by public and private tankers) for their everyday needs.

Ironically, the 2003-04 crisis acted as a catalyst for privatisation of water where it was justified more as a compulsion than indulgence. The crisis broke the linkage between water access and citizenship rights, ushering instead a fragmentary landscape dominated by consumer oriented models (Gandy 2004). Most Valmiki Nagar residents expressed a willingness to purchase water rather than the drudgery of voluntary collective action for a commodity that was seriously rationed. This sense of paying for services comes from a larger revelation of residents as consumers in the neoliberal climate, where their material interests have expanded not only to consumer durables but also public goods such as water, electricity, gas, telephones, which you pay and procure if possible from the public sector and if not, from the private suppliers.

In the end, it was mostly children from the nearby schools, members of a self-help group attached to the lower class settlement in the village, along with hired labour of a local contractor and the Corporation staff who helped clean the tank. The fishermen had a peripheral role as many indicated that involving them would complicate the process. Fishermen generally mobilise through the electoral platform and the patronage of local leaders attaching little significance to partnerships with the civil society. More importantly, the fishermen community's relationship with the temple is a historically longstanding one where they have a clearly etched out sociocultural role in its annual festivities. ${ }^{19}$ In this context, environmental activists from

\footnotetext{
${ }^{19}$ Since the focus of this paper is on bourgeois grassroots environmentalism, most of the qualitative fieldwork undertaken involved interviews with middle-class members. Participant observation revealed overt and covert ways through which the poor and the marginal groups were kept out of the exercise,
} 
both INTACH and Puduvellam felt uncomfortable meddling with some of these traditionally established power alignments. Also, given the narrow framework of the latter as a primarily small-scale, limited resources community initiative, it displayed little stamina or resolve to steer the different social groups through the process. Instead, it chose to train its guns on the familiar, i.e. the middle class.

Unfortunately for Puduvellam, it found itself unable to stimulate much enthusiasm amongst the middle class residents, encountering a condescending attitude towards its cause and campaign. For most of the better-off members in the neighbourhood, such self-help programmes and grassroots initiatives are meant for the poor who are the 'have-nots', amidst a conviction that the 'haves' do not need bottomup engagement. Puduvellam, in their viewpoint, is more beneficial to the poorer community in the village who are unable to afford water through private means and that their own role in the initiative is not as partners but as (financial) patrons. 'Give someone money to do it [clean the tank], anybody will do it, the poor, the slumdwellers, the kuppam people, we don't have time for this', one resident argued. This argument of paying the poor to clean the tank was prevalent amongst many middle-class residents, little realising that doing so strips them of a sense of ownership in the scheme as well as forestalling a genuine politics of partnership. Their concern is that a grassroots approach to resolving the water crisis forces them onto a platform where they have to negotiate an alliance with disparate groups based on democratic purity ( $c f$. Mitlin 2001). Less inclined to smooth differences in power and resources, residents view Puduvellam as a charitable institution to which they can at best make monetary contributions but not commit to personal participation. Thus, even though Puduvellam was initiated by a resident of Valmiki Nagar to ensure a grassroots presence of residential communities, residents have turned the project outwards, and placed their interest as outsiders looking in.

At best they viewed it as a beautification exercise. A preoccupation with clearing out the encroachments and resolving some of the traffic issues in the area distracted the residents from the primary aim of water management. Even though 
many realised the role of the tank in replenishing the aquifer, their dream of a full tank at any cost glossed over the less visible issue of groundwater recharge. As the restoration project commenced, it became not so much about rainwater harvesting as it was an opportunity to clean up the tank and its surrounding area. Along with removing garbage the need to prevent 'unwanted people' from indulging in all kinds of 'anti-social activities' (from using it as an open toilet to drinking, gambling, eating meat, etc.) was repeatedly emphasised. While the encroachments were removed, promises of restoring the tank as a public space was only partially fulfilled, as barricades were erected to fence it off once the tank bed had been cleaned, and the kind of democratic space that INTACH envisioned and promised was never realised. For Puduvellam however, the scheme up to this point was more or less successful as the tank had been cleaned up, storm water drains redirected into the tank, and the chances of it functioning as a reservoir for rainwater harvesting seemed high (Figure 4).

Insert Figure 4 here

\section{After the crisis: Outdone by religion}

Puduvellam's officials insisted several times during the interviews that even though their activities were a specific response to the 2003-04 water crisis, they were also meant to generate a more general awareness about water conservation. Yet, a year later, they found themselves struggling to maintain momentum once 'the crisis tided over'. In December 2004, the city experienced an ecological disaster in the form of the Indian Ocean tsunami, followed by unprecedented floods during the 2005 northeast monsoons. Both these disasters prompted an environmental debate of a different nature. Discussions ensued in terms of whether this could have been contained had we better managed the development of our coastline. An attempt to rewrite the existing Coastal Regulation Zone (CRZ) followed, with most environmentalists headbutting the state on revised drafts of the CRZ. In this context, the agenda of the civil society groups that were initially involved in the tank restoration project changed. Also, in 2005, following an excellent spell of monsoons, the city's reservoirs overflowed and the tank also brimmed with water. There was a lull in restoration efforts with the retreat of most of the non-state actors. 
In 2006, the DMK returned to state power, placing under the scanner many of the initiatives of the ADMK government. While it assured support for restoration of temple tanks, it was less inclined to toe the civil society-led, bottom-up route, relegating power back to the state. But in 2008, when the HRCE minister announced yet another proposal to renovate the Marundeeswarar Temple tank, there was concern as to whether this is one of those endless schemes that goes through several launches but is never completed. ${ }^{20}$ As the state took control, questions were raised over the role the tank would play in a re-imagined public space. Following an unfortunate incident in 2007 where two children drowned in the tank, the temple locked up the already barricaded tank, highlighting the problematic understanding of the temple as a public space refusing to conform to the norms of a modern democratic state.

In early 2009, the temple authorities announced the revival, after many years, of the float festival (teppotsavam) as part of the annual Panguni Thiruvizha in April, when the deity from the main shrine is taken on a float to the pavilion in the middle of the tank for special rituals. While older residents rejoiced at the idea of reviving an age-old tradition, little did they realise that the temple in preparation for the festival had dug eight deep borewells in the tank to source at least 1 mld of water. ${ }^{21}$ Residents in the nearby areas felt its impact immediately as they found their groundwater table dropping rapidly and feared seawater intrusion. This issue seemed a perfect opportunity for an organisation like Puduvellam to reactivate locally. But as Puduvellam's founder confessed, while the organisation still exists, his 'lone-ranger' kind of activism has been distracted by his more recent attempts to fight the state against the abuse of CRZ and relocation of the fishermen after the tsunami. INTACH similarly has moved on to other heritage related issues in the city. This is not surprising, as such initiatives, especially those led and dominated by the middle class are often constructed in response to a particular problem and find it hard to sustain

\footnotetext{
${ }^{20}$ The Hindu (2008, 11 July). Stress on renovating temple tanks. The Hindu. Chennai, p. 4. His announcement mentioning the laying of a two-feet deep clay bed for controlled percolation of rainwater made one wonder what kind of restoration took place in the previous years. There are also scientific concerns around the use of clay beds in lining the tank. While it is helpful in retaining rainwater, it does not facilitate its percolation because of which adequate groundwater recharge does not take place. Ganesan (2008) in her study advocates the use of alluvial soil instead of clay lining but this suggestion has rarely been adopted by the state, as clay beds tend to fill the tank up faster with water.
} 
themselves in the absence of one. Their activities peak at the boiling point of a specific crisis, and once abated, they return to their own tasks. Puduvellam's founder clarified that he tried to bring the different resident groups together suggesting the possibility of a common demonstration in front of the temple but was not successful, with the newly revived residents' assocation of Valmiki Nagar (VAREWA) deciding 'to go solo'. Realising the seriousness of the problem posed by groundwater extraction in the temple tank, VAREWA filed a judicial writ petition and started an online petition to gather support. When asked whether they considered more grounded forms of protest with other social groups, one of its members explained that it was not possible given their busy schedules which did not allow them the "luxury of demonstrations'. He added that filing a petition takes less time and effort, and felt reassured by the 'professional way' in which the issue was handled. Within a few months, the Madras High Court acting on the petition ordered the HRCE to stop groundwater extraction, thereby lending credibility to VAREWA's way of getting things done.

In many ways, Marundeeswarar temple tank's restoration could no longer be framed by a simple objective of rainwater harvesting. Rather, extending Hancock's argument (2002, 2008), new aspects of contestation became apparent not only between the state and civil society, but also between ritual actors and local citizens about the role of religious spaces and its practices in civic life and political participation. In a significant way, the manner in which the tank's restoration morphed shows the pivotal role of the temple in providing an organising framework for the surrounding community in its own terms, as it clearly was able to bend development rules for an episodic annual event (teppotsavam). The temple not only continues to function as an elite institution sustaining a social hierarchy drawn from the centralised authority of the state, but was also able to cut short a much needed environmental intervention, using it instead to cleverly restore and enhance its own mythical status.

\footnotetext{
${ }^{21}$ The temple also commissioned nearly 400 lorry loads of water from Metro Water supplied at a highly subsided rate.
} 


\section{Conclusions}

On $31^{\text {st }}$ July 2010 the DMK Chief Minister, M Karunanidhi, inaugurated with much fanfare what was trumpeted as South Asia's biggest desalination plant at Kattupalli (Minjur) in northern Chennai. Established on a 60-acre site at a cost of Rs. 600 crores (£85 million) and a production capacity of $100 \mathrm{mld}$, its opening marked the culmination of a long drawn out process first initiated in 2004. This ambitious publicprivate partnership project boasting international technological know-how was one of the solutions that had been mooted in response to the 2003-04 water crisis. Realised after much uncertainty, the decision of the state to proceed with yet another megainfrastructure solution is surprising given the multiple failures of such schemes from the earlier modernisation era. While this paper has discussed the enamour of the Indian and the Dravidian Tamil state with mega projects, its persistence needs to be seen under a new light, where gigantic engineering interventions are now a magnet for global capital, emphasising the technical excellence of a globally competitive, entrepreneurial state. Despite questions being raised over the usefulness of this solution in terms of social, economic and environmental sustainability, the state is pressing ahead with a second desalination plant in the city's southern periphery.

This technological route reveals an inherent paradox in the state management of the city's water resources, as it sits comfortably alongside its other equally highprofile and seemingly more sustainable initiative, i.e. rainwater harvesting. Despite their contrasting approach, both solutions were brought together by an urgent need to reassure the concerned citizens that 'concrete' steps were being taken to address the water question. As the city's main water supply source shifted from surfacewater to groundwater, environmental activists were well-aware that the state mandate on rainwater harvesting was hardly sufficient in restoring the city's depleted aquifers. They recognised and emphasised the need for wider rainwater harvesting interventions in the public realm for a more meaningful impact. Using the state campaign for rainwater harvesting as a license, several environmental groups, took up its cause at a larger scale, mostly focussing on restoring traditional (pre-colonial) tank-based techniques of water resources management. Exemplar projects were undertaken to restore landmark temple tanks in the city which in their pre-colonial 
heydays had successfully combined the symbolic capital of religion with the political economy of the region.

One among them is the Marundeeswarar temple in Thiruvanmiyur, where riding on the momentum set up by the city chapter of a national heritage NGO (INTACH) to rejuvenate the temple and its premises, an environmental activist from the adjoining middle class neighbourhood of Valmiki Nagar established a communitybased organisation, Puduvellam to energise the efforts of INTACH through further grassroots participation. Presented as an effort to generate a 'civic governmentality' (Roy 2009) where grassroots organisations could create a sustainable public realm, Puduvellam despite its early success was eventually incapable of reconciling the aspirations of different actors. As a result the temple tank quickly became a site of tension where its re-imagination at the end had to comply with the ideology of the state. While part of the reason can be traced to literature which challenges the idea of governmentality from below (Roy 2009), a greater share can be attributed to the fact that organisations such as Puduvellam do not cohere together entirely as a civil society. As Puduvellam tried to manoeuvre the differences between the different socio-political actors, it found itself hampered by a classic middle class paradox where, as dominant members of this community-based exercise, the middle class contributed sufficiently in terms of financial patronage but undermined its objective through their own presence as an amalgam of consumers, not citizens. The 2003-04 crisis ironically hastened the transformation of water from a public good into a marketable commodity as a result of which water could no longer be understood as an integral component of modern citizenship rights.

The class and caste prejudices that played out in this process notwithstanding, Puduvellam also suffered from condescension of the dominant middle class residents in its vicinity that grassroots initiatives are for the have-nots, not the haves, as a result of which they failed to see the larger socio-ecological benefit of restoring the tank. This rejection was aided by the reliance of the middle class on private means of service provision making them less willing to promote the temple tank's rehabilitation as a public exercise. Middle-class associations in this scenario revealed their position as citizen-consumers, wherein they secured their rights as citizens through their consumerist bargaining. There is an urgent need to speculate on 
how the emerging role of residents as citizen-consumers affects efforts such as rainwater harvesting, especially in a context where the balance is clearly tipped in the hyphenated condition, and the resident as a consumer chooses to deploy him-/herself as a citizen for his-/her own consumption gains. In this scenario, there is not only a sense of uselessness in whipping up a citizen-like frenzy, but also some amount of harm and danger as much of this mass coalescence is wasted over an ideology of privatism and individualism. VAREWA's intervention in the tank politics in 2009 is indicative of the behaviour of closed associations of modern elite groups sequestered from the wider popular life of the communities. While it sought to assert its power through the support of the legal domain, it did not represent a cogent public, and in the end the temple retained its right to the tank highlighting further the anomaly in harvesting water as a common good. The actions of the temple showed the futility of romanticising the historical legacy of temple tank-based rainwater harvesting as it emphasised the temple as an agency of the state that seeks to sustain the hierarchical basis of socio-ecological relationship between nature and society.

Most residents in their interviews concluded that Puduvellam was a good intention that had run its course and that one cannot expect too much from such a small initiative. While there is a sense of fatalism here, this paper shows that the running aground resulted from the inability of this grassroots initiative to negotiate the complex politics that emerged from the differing ideologies of the various sociopolitical actors involved. More importantly, the ability of Puduvellam to have a greater impact was tempered by the behaviour of its prominent support group, the middle class, who reduced its concerns to an aesthetic improvement of the temple tank. Even though Puduvellam's promotion of rainwater harvesting tried to extend the historic dialectic between water and urbanisation to include a wider definition of the public realm, its efforts were thwarted by a growing tendency to privatise and commodify water. While Puduvellam per se is not an ally of capitalist urbanisation, its discourse is set against the organising force of 'bourgeois environmentalism' (Baviskar 2003) where concerns of aesthetics, leisure, safety, and health have come to significantly shape the disposition of urban spaces. With a tendency to disguise rather than address the inadequacies of urban infrastructure (Gandy 2008), bourgeois environmentalism can disrupt the objective of rainwater harvesting by reducing its concern to an irrelevant and superficial level. As the trend of bourgeois 
environmentalism converges with the water urbanisation strategies of the state, the problems associated with community-led rainwater harvesting efforts in the public realm signal more than a good intention gone wrong. Consequently, it is going to be difficult for this misplaced ideology to ensure an expansively conceptualised environment integrating the social and the natural.

\section{References}

Agawam, A. and S. Narain (1997). Dying wisdom: Rise, fall and potential of India's traditional water harvesting systems. New Delhi, Centre for Science and Environment.

Anjaria, J. S. (2009). "Guardians of the bourgeois city: Citizenship, public space, and middle-class activism in Mumbai." City \& Community 8(4): 391-406.

Appadurai, A. (2002). "Deep democracy: Urban governmentality and the horizon of politics." Public Culture 14(1): 627-651.

Arabindoo, P. (2009). "Falling apart at the margins? Neighbourhood transformations in peri-urban Chennai." Development and Change 40(5): 879-901.

Bandyopadhyay, J. and S. Perveen (2004). "Interlinking of rivers in India: Assessing the justifications." Economic and Political Weekly 39(50): 5307-5316.

Baud, I. and N. Nainan (2008). "'Negotiated spaces" for representation in Mumbai: Ward committees, advanced locality management and the politics of middleclass activism." Environment and Urbanization 20(2): 483-499.

Baviskar, A. (2003). "Between violence and desire: Space, power and identity in the making of metropolitan Delhi." International Social Science Journal 55(1): 89-98.

Chakrabarty, D. (1992). "Of garbage, modernity and the citizen's gaze." Economic and Political Weekly 27(10-11): 541-547.

Chatterjee, P. (2004). The politics of the governed: Reflections on popular politics in most of the world. New York, Columbia University Press.

CMDA (2007). Second Master Plan - II. Chennai, Chennai Metropolitan Development Authority.

Coelho, K. and T. Venkat (2009). "The politics of civil society: Neighbourhood associationism in Chennai." Economic and Political Weekly 44(26/27): 358367.

Davis, M. (1992). City of quartz: Excavating the future of Los Angeles. New York, Vintage.

Fernandes, L. (2006). India's new middle class: Democratic politics in an era of economic reform. Minneapolis, University of Minnesota Press.

Gandy, M. (2004). Water, modernity and emancipatory urbanism. The emancipatory city?: Paradoxes and possibilities. L. Lees. London, Sage Publications: 178191.

Gandy, M. (2006). "Planning, anti-planning and the infrastructure crisis facing metropolitan Lagos." Urban Studies 43(2): 371-396.

Gandy, M. (2008). "Landscapes of disaster: Water, modernity, and urban fragmentation in Mumbai." Environment and Planning A 40(1): 108-130. 
Ganesan, M. (2008). "The temple tanks of Madras, India: Rehabilitation of an ancient technique for multipurpose water storage." Indian Journal of Science and Technology 1(7): 1-8.

Gupta, D. (2000). Mistaken modernity: India between worlds. New Delhi, Harper Collins.

Hancock, M. (2002). "Modernities remade: Hindu temples and their publics in southern India." City \& Society XIV(1): 5-35.

Hancock, M. E. (2008). The politics of heritage from Madras to Chennai. Bloomington IN, Indiana University Press.

Harriss, J. (2005). "Middle class activism and poor people's politics: An exploration of civil society in Chennai." London, Development Studies Institute (DESTIN), London School of economics and Political Science.

Harriss, J. (2006). "Middle-class activism and the politics of the informal working class: A perspective on class relations and civil society in Indian cities." Critical Asian Studies 38(4): 332-346.

Harriss, J. (2007). "Antinomies of empowerment." Economic and Political Weekly 42(26): 2716-2724.

Janakarajan, S. (1993). "In search of tanks: Some hidden facts." Economic and Political Weekly 28(26): A53-A60.

Janakarajan, S., J. Butterworth, et al. (2007). "Strengthened city, marginalised periurban villages: Stakeholder dialogues for inclusive urbanisation in Chennai, India." Peri-urban water conflicts: Supporting dialogue and negotiation. J. Butterworth, R. Ducrot, N. Faysse and S. Janakarajan. Delft, IRC International Water and Sanitation Centre: 51-76.

Kamath, L. and M. Vijayabaskar (2009). "Limits and possibilities of middle class associations as urban collective actors." Economic and Political Weekly 44(26/27): 368-376.

Kashwan, P. (2006). "Traditional water harvesting structure: Community behind 'community'." Economic and Political Weekly 41(7): 596-598.

Kaviraj, S. (1997). "Filth and the public sphere: Concepts and practices about space in Calcutta." Public Culture 10(1): 83-113.

Kosambi, M. and J. E. Brush (1988). "Three colonial port cities in India." Geographical Review 78(1): 32-47.

Krishnaswami, V. D. (1994 [1939]). "The problem of water in Madras." The Madras Tercentenary commemoration volume. Madras Tercentenary Celebration Committee. Madras and New Delhi, Asian Educational Services: 283-294.

Kumar, M. D. (2004). "Roof water harvesting for domestic water security: Who gains and who loses?" Water International 29(1): 43-53.

Kumar, M. D., S. Ghosh, et al. (2006). "Rainwater harvesting in India: Some critical issues for basin planning and research." Land Use and Water Resources Research 6: 1-17.

Lama-Rewal, S. T. (2007). "Neighbourhood associations and local democracy: Delhi municipal elections 2007." Economic and Political Weekly 42(47): 51-60.

Lewandowski, S. (1975). "Urban growth and municipal development in the colonial city of Madras, 1860-1900." The Journal of Asian Studies 34(2): 341-360.

Lewandowski, S. (1977). "Changing form and function in the ceremonial and the colonial port city in India: An historical analysis of Madurai and Madras." Modern Asian Studies 11(2): 183-212.

Lewandowski, S. (1979). "Urban planning in the Asia port city: Madras, an overview, 1920-1970." South Asia: Journal of South Asian Studies 2(1): 30-45. 
Ludden, D. (1979). "Patronage and irrigation in Tamil Nadu: A long-term view." The Indian Economic and Social History Review XVI(3): 347-365.

Maria, A. (2008). Urban water crisis in Delhi: Stakeholders responses and potential scenarios of evolution. Paris, Iddri - Idées pour le débat $\mathrm{N}^{\circ} 06$.

Mawdsley, E. (2004). "India's middle classes and the environment." Development and Change 35(1): 79-103.

McFarlane, C. (2008a). "Postcolonial Bombay: Decline of a cosmopolitan city?" Environment and Planning D: Society and Space 26(3): 480-499.

McFarlane, C. (2008b). "Governing the contaminated city: Infrastructure and sanitation in colonial and post-colonial Bombay." International Journal of Urban and Regional Research 32(2): 415-435.

McFarlane, C. and J. Rutherford (2008). "Political infrastructures: Governing and experiencing the fabric of the city." International Journal of Urban and Regional Research 32(2): 363-374.

Mitlin, D. (2001). "Civil society and urban poverty - examining complexity." Environment and Urbanization 13(2): 151-173.

MMDA (1971). Madras metropolitan plan, 1971-1991. Rural Development and Local Administration Department. Madras, Madras Metropolitan Development Authority.

Mosse, D. (1997a). "The symbolic making of a common property resource: History, ecology and locality in a tank-irrigated landscape in South India." Development and Change 28(3): 467-504.

Mosse, D. (1997b). "The ideology and politics of community participation: Tank irrigation development in colonial and contemporary Tamil Nadu." Discourses of development: Anthropological perspectives. R. D. Grillo and R. L. Stirrat. Oxford and New York, Berg: 255-292.

Mosse, D. (1999). "Colonial and contemporary ideologies of 'community management': The case of tank irrigation development in South India." Modern Asian Studies 33(2): 303-338.

Mosse, D. (2001). "Irrigation and statecraft in zamindari south India." The everyday state and society in modern India. C. J. Fuller and V. Benei. London, C Hurst \& Co: 163-193.

Mosse, D. (2003). The rule of water: Statecraft, ecology and collective action in South India. Oxford, Oxford University Press.

Mukundan, T. M. (1988). "The ery systems of South India." PPST Bulletin 16: 1-33.

Nair, K. S. (2004). "Role of water in the development of civilization in India-a review of ancient literature, traditional practices and beliefs." The basis of civilization - water science? J. C. Rodda and L. Ubertini. Wallingford, International Association of Hydrological Sciences: 160-166.

Neild, S. M. (1979). "Colonial urbanism: The development of Madras city in the eighteenth and nineteenth centuries." Modern Asian Studies 13(2): 217-246.

Palaniswami, K. and R. Meinzen-Dick (2001). "Tank performance and multiple uses in Tamil Nadu, South India." Irrigation and Drainage Systems 15(2): 173-195.

Reddy, V. R. (1990). "Irrigation in colonial India: A study of Madras Presidency during 1860-1900." Economic and Political Weekly 25(18/19): 1047-1054.

Robson, G. and T. Butler (2001). "Coming to terms with London: Middle-class communities in a global city." International Journal of Urban and Regional Research 25(1): 70-86.

Roy, A. (2003). "Paradigms of propertied citizenship: Transnational techniques of analysis." Urban Affairs Review 38(4): 463-491. 
Roy, A. (2009). "Civic governmentality: The politics of inclusion in Beirut and Mumbai." Antipode 41(1): 159-179.

Rudolph, L. I. (1961). "Urban life and populist radicalism: Dravidian politics in Madras." The Journal of Asian Studies 20(3): 283-297.

Sakurai, T. and K. Palaniswami (2001). "Tank irrigation management as a local common property: The case of Tamil Nadu, India." Agricultural Economics 25(2-3): 273-283.

Sengupta, N. (1985). "Irrigation: Traditional vs modern." Economic and Political Weekly 20(45/47): 1919-1938.

Shah, E. (2008). "Telling otherwise A historical anthropology of tank irrigation technology in South India." Technology and Culture 49(3): 652-674.

Srinivasan, V. (2008). An integrated framework for analysis of water supply strategies in a developing city: Chennai, India. Environment and Resources. Stanford CA, Stanford University. PhD.

Srinivasan, V., S. M. Gorelick, et al. (2010). "Sustainable urban water supply in south India: Desalination, efficiency improvement, or rainwater harvesting?" Water Resources Research 46(W10504): doi:10.1029/2009WR008698.

Srivathsan, A. (2000). "Politics, popular icons and urban space in Tamil Nadu." Twentieth-century Indian sculpture: The last two decades. S. K. Panikkar. Mumbai, Marg Publications: 108-117.

Srivathsan, A. (2006). "Politics, architecture and the city." Chennai, not Madras: Perspectives on the city. A. R. Venkatachalapathy. Mumbai, Marg Publications: 49-62.

Subramanian, N. (1999). Ethnicity and populist mobilization: Political parties, citizens and democracy in South India. Delhi, Oxford University Press.

Swyngedouw, E. (1997). "Power, nature, and the city. The conquest of water and the political ecology of urbanization in Guayaquil, Ecuador: 1880-1990." Environment and Planning A 29(2): 311-332.

Vaidyanathan, A., Ed. (2001). Tanks of South India. New Delhi, Centre for Science and Environment.

Vaidyanathan, A. (2003). "Interlinking of peninsular rivers: A critique." Economic and Political Weekly 38(27): 2865-2872.

Vaidyanathan, A. (2006). India's water resources: Contemporary issues on irrigation. New Delhi, Oxford University Press.

Veron, R. (2006). "Remaking urban environments: The political ecology of air pollution in Delhi." Environment and Planning A 38(11): 2093-2110.

Washbrook, D. (1989). "Caste, class and dominance in modern Tamil Nadu: NonBrahmanism, Dravidianism and Tamil nationalism." Dominance and state power in modern India: Decline of a social order - Volume I. F. R. Frankel and M. S. A. Rao. Delhi, Oxford University Press: 204-264.

Widlund, I. (2000). Paths of power and patterns of influence: The Dravidian parties in South Indian politics. Uppsala, University of Uppsala.

Zerah, M.-H. (2007). "Middle class neighbourhood associations as political players in Mumbai." Economic and Political Weekly 42(47): 61-68. 